\title{
Flow Studies using Laser Anemometry Technique in a Small Power Unit Radial Inflow Turbine
}

\author{
SOHAIL H ZAIDI ${ }^{\mathrm{a}, *}$ and ROBIN L ELDER ${ }^{\mathrm{b}}$ \\ ${ }^{a}$ Research Fellow, Cranfield University, Bedford MK43 OAL, UK; ${ }^{\mathrm{b}}$ Professor and Head of Turbomachinery and Engg. Mechanics \\ Group, Cranfield University, BEDS MK43 OAL, UK
}

(Received 11 April 1996; In final form 17 May 1996)

\begin{abstract}
T-100 is a multipurpose small power unit developed by Sundstrand Power Systems (USA). An extensive research programme was launched for the detailed tests of the rig components including inlet protection system, Compressor stage, Combustor and the Turbine stage. Turbomachinery Group at Cranfield was involved in the study of the Turbine unit used in this programme. From the design point of view, detailed aerodynamics in these small units are of great interest especially where high velocities and narrow passages are involved. Experimental study was carried out to investigate the flow in the region between the nozzle guide vanes and the turbine rotor entry. The main concern was to find out how the nozzle guide vane flow was modified by the rotor and how the rotor flow was affected by the nozzle guide vanes. Laser measurements were taken at these positions for various flow conditions. An other area which needs considerable attention is downstream of the turbine rotor where the turning of flow and mixing process make the situation very complicated. Laser studies were undertaken in that region and to gain more confidence on laser results, a Cobra pressure probe was traversed at these stations. This paper describes various steps undertaken to obtain laser results within the machine. At the end typical laser results have been presented and discussed.
\end{abstract}

Keywords: Radial Inflow Turbine, Laser Anemometry, Turbomachinery, Flow mixing, Nozzle Guide Vanes

\section{INTRODUCTION}

The T-100 Multipurpose Small Power Unit was developed by Sundstrand Power Systems (USA) for airborne, mobile vehicle and ground power applications. This unit has the power capabilities from 50 to 100 shaft horse power. The details of various com- ponents including the compressor, the combustor and the turbine stage has been explained by Napier [1991]. The small high pressure Radial Inflow Turbine used in this power unit has been tested and the performance results have been presented by Napier [1988] and Jones [1994]. Cranfield was provided with the turbine hardware which included a rotating

*Corresponding author. Tel.: 0115-9514163, ext. 8122. Fax: 0115-9514181. E-mail: sohail.zaidi@uk.ac.nottnmc 
assembly, bearing housing, nozzle guide vanes and the turbine scroll to conduct a series of experiments for flow measurements within the machine using laser Anemometry Techniques.

Use of laser anemometry technique for flow investigation in high speed rotating radial inflow turbines has recently gained considerable attention, Zaidi and Elder [1993], Eroglu [1990] and Murugan and Tabakoff [1994]. The main reason for this attention is their industrial application where they are commonly used as a component for compact gas turbine engines. The turbine performance is critical and of great importance for the success of these systems and therefore experimental studies are being carried out to understand the ill-defined and complicated phenomenon occurring within these machines, Huntsman [1991], Pullen [1992] and Gullus [1992].

The Turbine provided for this study had sixteen blades and nineteen nozzle guide vanes. The unit does not contain any exit guide vanes. A co-axial compressor was used as a break to absorb the turbine output. A test rig available at Cranfield was modified to accept this unit. The test rig facility has been shown in figure (1). The turbine was powered by a plant air compressor. An ejector at the exhaust of the turbine was used to achieve various expansion ratios across the turbine. In this way different operating conditions were achieved to perform the laser work. The test cell is well equipped with the instruments to provide an on-line data acquisition system to monitor and update the turbine performance. The design expansion ratio for the turbine was 5.7 at a corrected

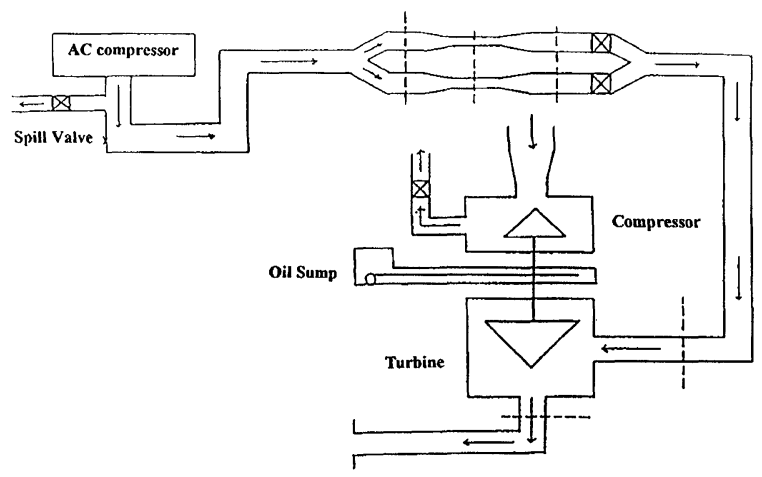

FIGURE 1 Schematic Diagram for the rig installation. speed of approximately $51,000 \mathrm{rpm}$. For this study the unit was operated at lower speeds but appropriate inlet flow angles were established. Following operating conditions were used to carry out the laser work.

Turbine expansion ratio $=3.0,3.5$

$$
\mathrm{U} / \mathrm{V}=.64, .68, .70, .72
$$

where $\mathrm{U}$ is the rotor tip speed and $\mathrm{V}$ is the gas speed at the rotor inlet.

The laser anemometry work was performed in the region between the nozzle guide vanes and the turbine entry for various locations and operating conditions. The particular interest in this area is to understand the flow in and around the nozzle guide vanes. The laser anemometry results were obtained in the absolute frame of reference and then were transposed in the rotor relative frame of reference in order to see any possible effect of the rotating blades on the flow in that region. Strobing was carried out to examine this blade passing effect.

The flow downstream of the rotor is of a very complicated nature. The wheel turns the flow from the radial to axial direction. It is of interest to investigate the ability of rotor wheel to perform this flow turning uniformly. The mixing process downstream the rotor is also ill-defined. The laser anemometry work was carried out at two stations located $35 \mathrm{~mm}$ and 192.5 $\mathrm{mm}$ downstream of the rotor trailing edge tip. The flow was investigated at various radial positions from the wall of the casing to the centre of the duct, the details of which have been presented in the following sections.

\section{LASER ANEMOMETRY SYSTEM}

Mechanical design involved in small machines do not allow the use of laser anemometry systems in forward scattering mode. Only one optical access is possible in which case laser systems with full backscatter arrangements are employed. In this study a Malvern Instruments 4772 laser anemometer (in the time of flight mode) was used. The principle of laser transit 
anemometry and its suitability for turbomachines has been given in detail by Schodl [1974]. The laser anemometry data was processed to give gas velocities and turbulent intensities. The data reduction programme was based on the theory given by Ross [1986].

\section{OPTICAL ACCESS}

\section{Nozzle Guide Vane Area}

Area between the nozzle guide vanes and the turbine rotor entry has been marked in figure (2). In order to take laser measurements in this region, optical windows were required. The design criterion for optical windows was that they should not disturb the flow in that region. To obtain such an optical window in this machine was a very tedious task as approach through the turbine back plate was not possible due to the mechanical complexities. The only way to reach the required area was through the plenum chamber as shown in the figure (3). In this case a special right angled cone with a mirror was designed and was inserted in the plenum chamber. Small pinholes $(2 \mathrm{~mm}$ diameter) were machined in the turbine assembly and the arrangements were made to locate the cone such

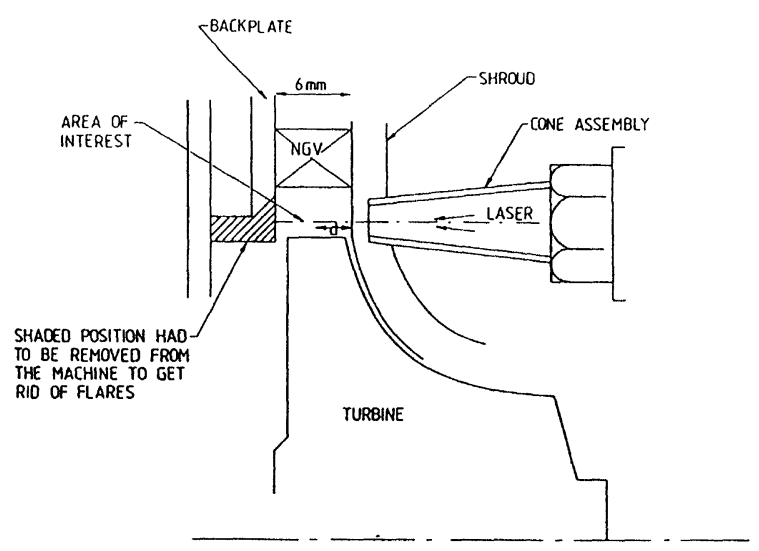

FIGURE 3 Installation of cone assembly in the plenum chamber to isolate laser beams from the flow.

that measurements could be taken at any required circumferential position. Five circumferential positions (W1-W5) were selected as shown in figure (4).

Window W1 lies at the trailing edge of the vane and has been taken as a datum position. The inner casing of the shroud was rotated with respect to this datum position to align the cone with the rest of the windows. After inserting the cone, the plenum chamber was sealed to avoid any gas leakage. The size of the cone was kept as small as possible to minimise the disturbance to the flow.

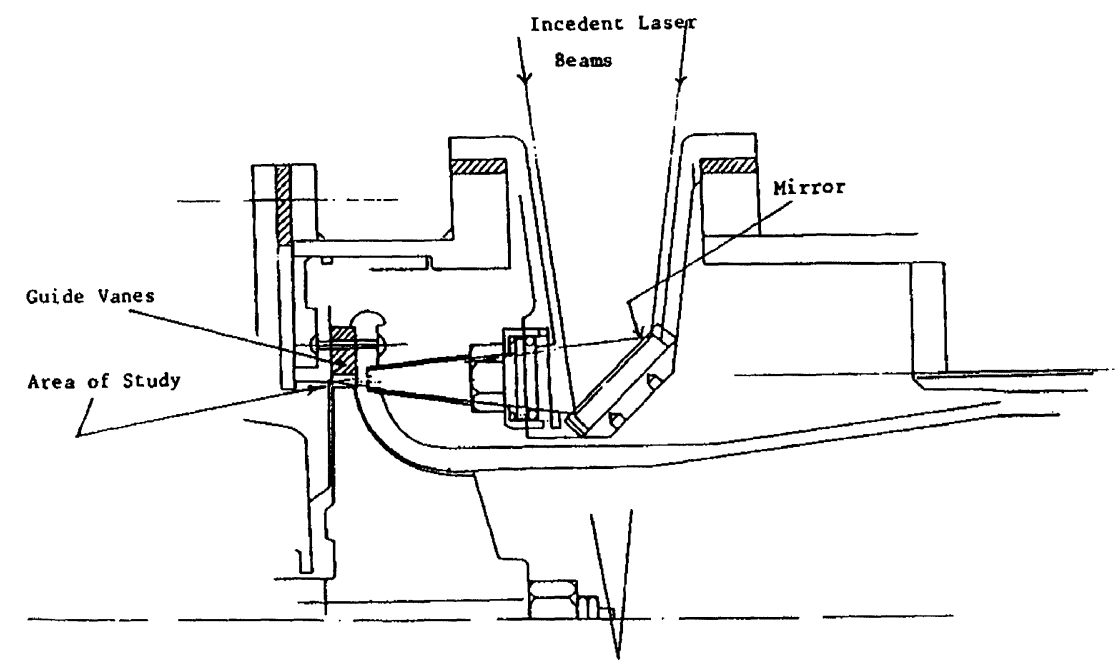

FIGURE 2 Region of interest at Turbine inlet to take laser Anemometry measurements. 


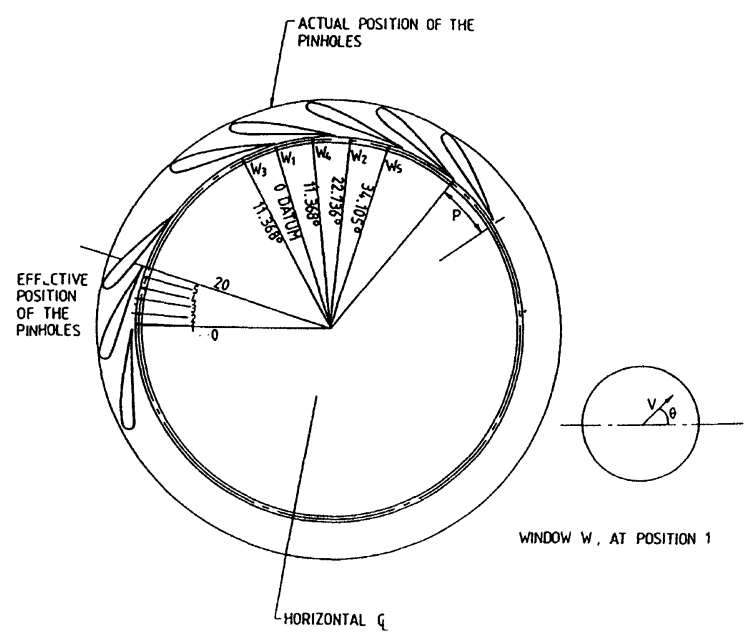

FIGURE 4 Pinhole positions at the Turbine inlet for laser measurements.

\section{Down Stream of the Rotor}

Two window locations were selected downstream of the rotor as shown in figure (5). One main problem encountered in designing the optical windows in this area were the subzero temperatures which were recorded during the operation. The temperature drop across the turbine rotor created subzero conditions. A layer of ice appeared on the glass windows which blocked the laser beams preventing any laser measurements. Subzero temperatures also caused an excess of liquid/solid particles making the flow impenetrable to the laser beam. The design of the optical

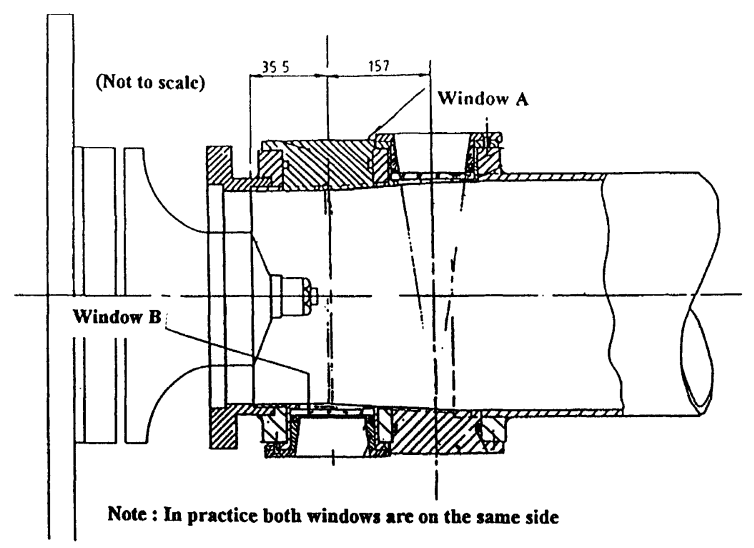

FIGURE 5 Windows for optical access at the Turbine exit. windows for such extremely harsh conditions needs special attention and been discussed elsewhere by Zaidi and Elder [Oct. 1993 and Aug. 1993].

Figure (5) shows the optical window arrangement used in this study. Pinhole windows were used and the pinhole diameter was increased in steps as the measurement volume within the duct moved away from the wall to the axis. Option to clean the window during the rig operation was also provided.

\section{LASER ANEMOMETRY RESULTS AND DISCUSSION}

\section{Nozzle guide vane area}

Laser measurements were taken at five circumferential positions (W1-W5) shown in figure (4). At these positions channel depth was approximately $6 \mathrm{~mm}$. Five stations were selected across the channel. As the temperature involved in this measurement were not high (up to $150^{\circ} \mathrm{C}$ ), silicon oil was used as the seeding material. A Dantec aerosol seeding generator producing the particles around a diameter of 0.5 microns was used. The seeding injection tube was located one meter upstream the plenum chamber to allow reasonable mixing of the seeding in the flow. The laser was focused at a point on the window casing which was marked as the datum point. All the distances were measured from that datum. when the rig was not in operation. After achieving the required operating conditions, distances were remeasured from this datum point in order to take into account any rig expansion.

Initial testing of the rig indicated the presence of the back ground noise due to the reflections from the back wall. In order to increase the signal to noise ratio, back ground flare was reduced by machining a small section (1 mm length) of the back wall as shown in the figure (3). Satisfactory laser results were obtained for each of the positions at various flow conditions. Two of the typical results have been shown in figure (6) for two running conditions (Expansion Ratio $=3.0,3.5 \& \mathrm{U} / \mathrm{V}=.70, .72)$. Velocities and flow angles have been averaged over the five windows. 

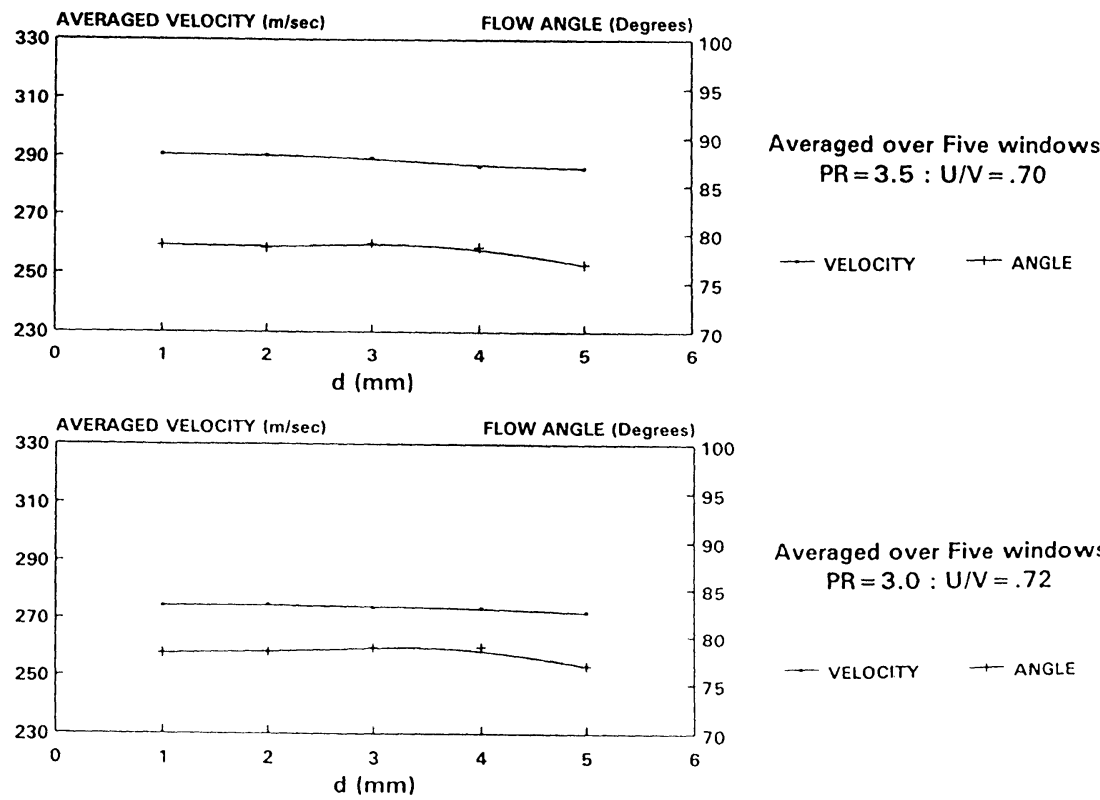

Averaged over Five windows $\mathrm{PR}=3.0: \mathrm{U} / \mathrm{V}=.72$

- VELOCITY + ANGLE

FIGURE 6 Laser Anemometry results at the Turbine inlet for various flow conditions.

The flow angle was defined from the horizontal position as shown in figure (4). Figure (6) shows little velocity and flow angle variations across the channel expect at $\mathrm{d}=5 \mathrm{~mm}$ where both velocity and flow angle reduce to a lower value. This effect was observed for almost all of the running conditions. Most probable reason for this variation is the near wall effect as this position is only $1 \mathrm{~mm}$ away from the back wall.

Variation of the average velocity with U/V at different stations across the channel has been shown in figure (7). At a lower value of U/V (=.64), velocity

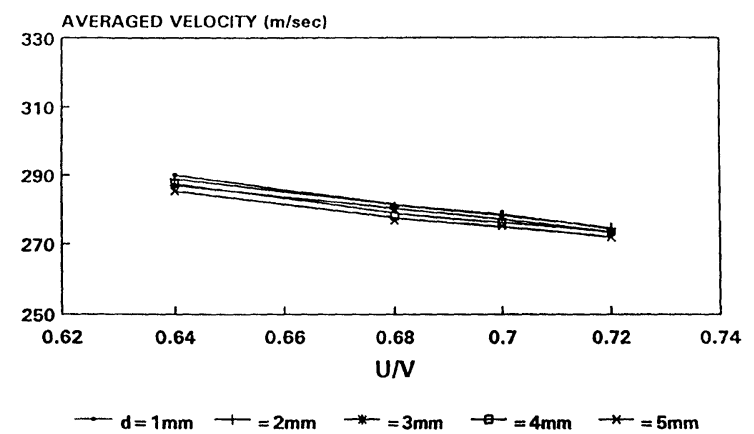

FIGURE 7 Variation of the averaged velocity with U/V for different positions across the channel. change across the channel is maximum as compared to the higher values of $\mathrm{U} / \mathrm{V}(=.72)$ for an expansion ratio of 3.0 whereas the change in flow direction is almost constant for the corresponding running conditions, figure (8). Both figures ( 7 and 8 ) have shown nozzle vane outlet conditions very uniform both spanwise and pitchwise. These flow conditions therefore provide the rotor with well defined and uniform inlet conditions.

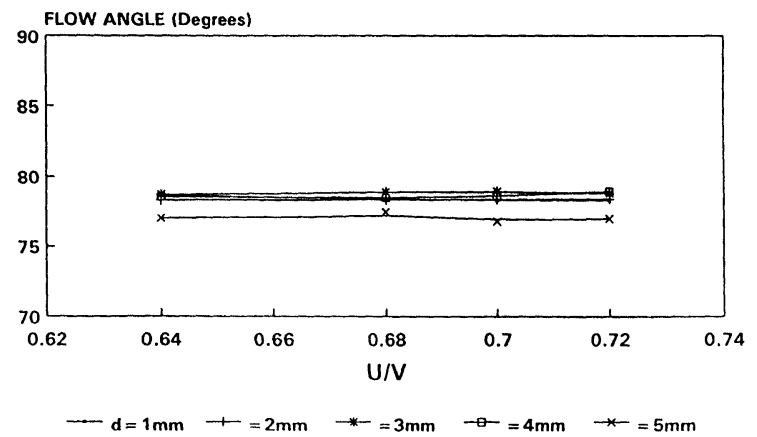

FIGURE 8 Flow angle variation with U/V for different positions across the channel. 


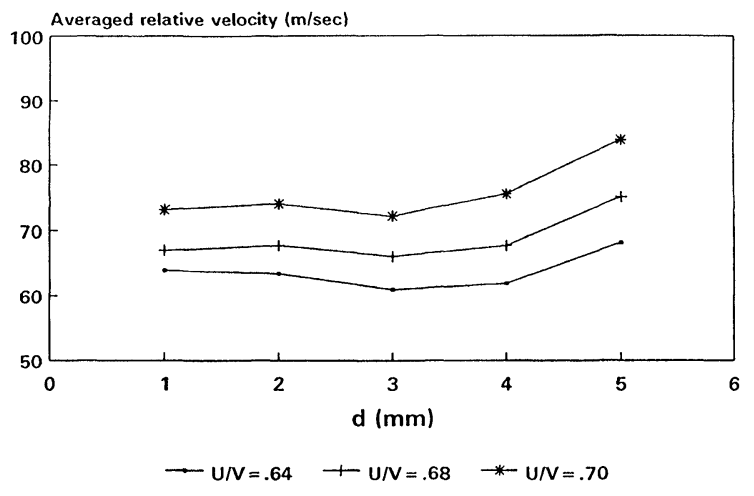

FIGURE 9 Pitchwise averaged relative velocity between the nozzle guide vanes and the Turbine rotor.

The velocity and flow angle results in absolute frame of reference were transposed into rotor relative frame of reference. Figure (9) shows an increase in relative velocities (averaged over five windows) for position at $\mathrm{d}=4,5 \mathrm{~mm}$, from the back wall whereas there is a very small change in the relative flow angles across the channel, figure (10). The incidence angle for the running conditions $(\mathrm{U} / \mathrm{V}=.64, .68, .70)$ was found to lie between -10 to -40 degrees and was almost constant across the channel for each condition, figure (11).

In order to find out the rotor blade passing effect at these positions strobing was carried out. Figure (12) shows the results for three windows. There is hardly any noticeable change in the flow velocity (relative) due to the rotor blade passage. These measurements shown in figure (12) have been taken at the mid pas-

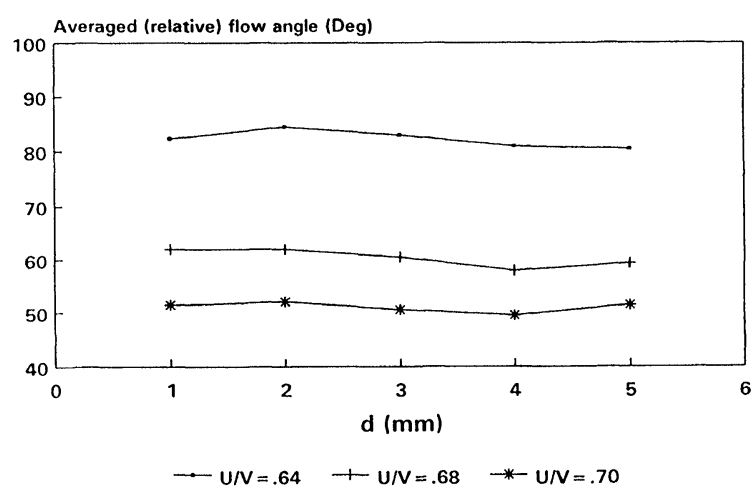

FIGURE 10 Pitchwise averaged relative flow angle between the nozzle guide vanes and the Turbine rotor.

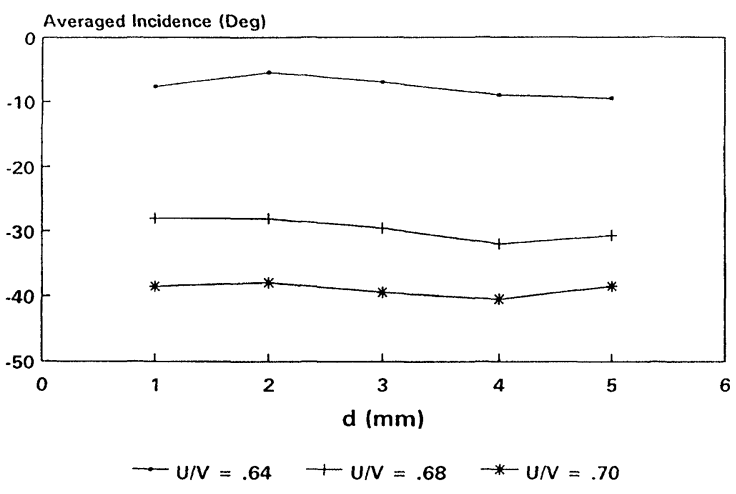

FIGURE 11 Pitchwise averaged incidence angle between the norzle guide vanes and the Turbine rotor.

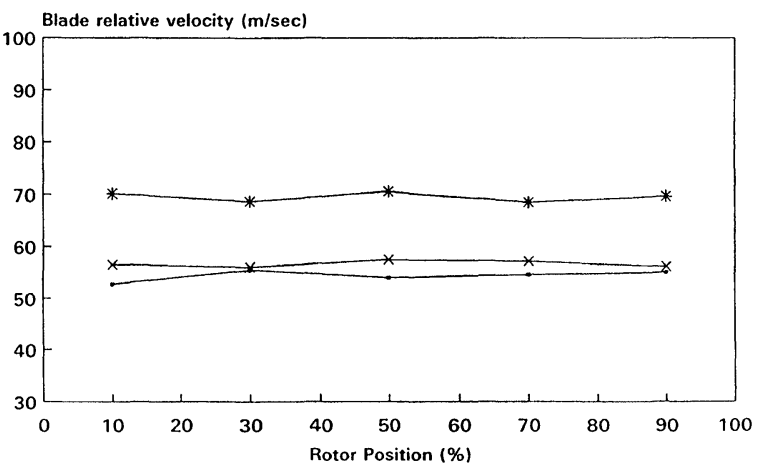

FIGURE 12 Strobing results for windows (W1, W3 \& W5) at PR 3.5 and $\mathrm{U} / \mathrm{V}=.68$

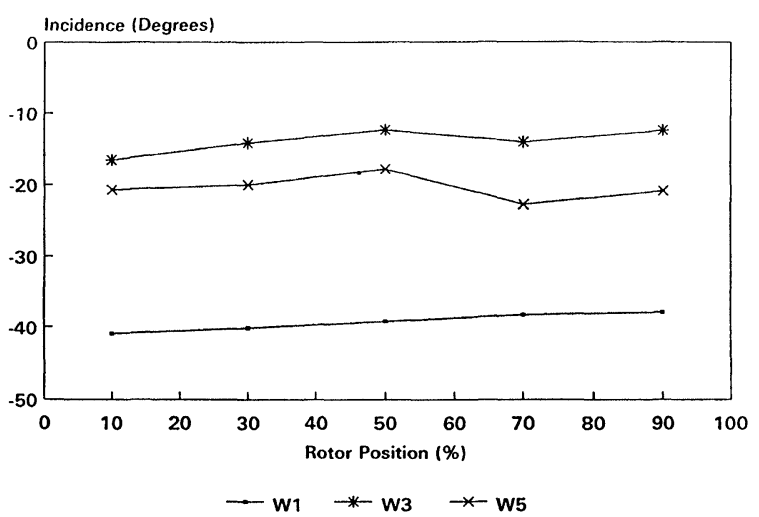

FIGURE 13 Strobing results for windows (W1, W3 \& W5) at PR 3.5 and $\mathrm{U} / \mathrm{V}=.68$ 
sage. Variation in the incidence angle due to the blade passing effect is noticeable particularly at window W3, figure (13), which lies almost in the middle of the nozzle guide vanes passage, figure (4). In general, the passing rotor blade had little influence on the nozzle guide vane flow.

\section{Turbine Exit}

Several problems were identified while taking laser measurements downstream of the turbine rotor. Firstly, the flow highly turbulent in that region and second, subzero temperatures were limiting the time in which measurements could be taken. Problems were overcome and successful results were achieved. Fifteen radial positions were selected to perform the laser work at windows $\mathrm{A}$ and $\mathrm{B}$, figure (5). Figure (14) shows the velocity results at window A for various flow conditions. Flow was scanned from the centre to the duct wall and it was possible to take laser measurements at position $2 \mathrm{~mm}$ away from the duct wall. Figure (14) indicates that no laser results could be obtained for the central annulus region of the graph (radius $=20-30 \mathrm{~mm}$ ) as this region was found highly turbulent and it was extremely difficult to position the seeding injection tube to get maximum seeding response in the region. Swirl angle changed from positive to negative values for this region, as shown in figure (15). Positive flow angle was defined as one where the rotation is in the same direction as

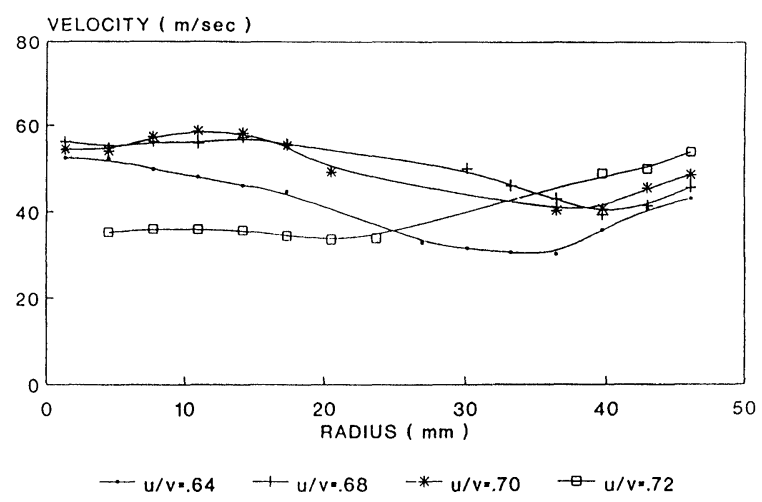

FIGURE 14 Laser Anemometry measurements downstream the Turbine rotor at station A.

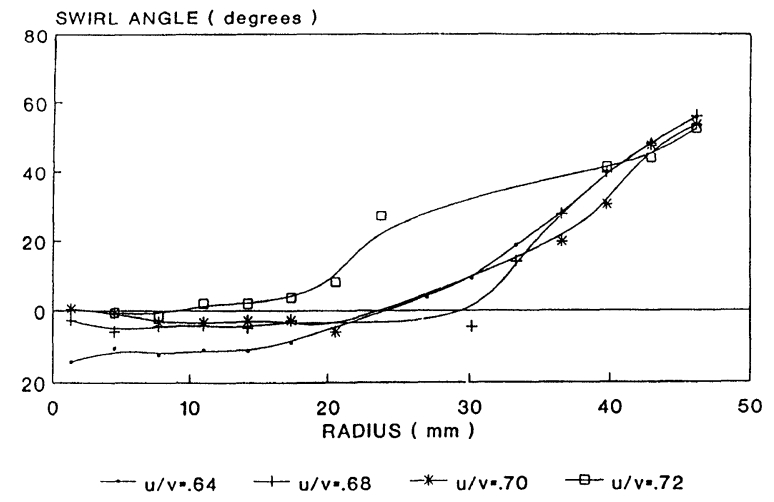

FIGURE 15 Laser Anemometry measurements downstream the Turbine rotor at station A.

the rotor and the flow moving away from the turbine, figure (16). Near the central region of the pipe, a swirl flow with negative angle has been observed indicating a region of counter rotating flow. In order to gain more confidence conventional measurements with a Cobra Yaw meter probe were made which could be compared with laser anemometry results at these locations. Figure (17) shows that swirl angle variations with the radius in both cases are similar. Cobra probe also confirmed a counter rotating flow at the centre of the annulus region. The minor difference in the flow angles is possibly due to the interaction of the Cobra probe with the flow. Laser anemometry being a non intrusive technique is felt to be more reliable in this confined region. Laser results were found to be very repeatable and in order to maintain the accuracy, three or more readings were taken for a single position and were averaged to produce a more accurate result at particularly difficult positions.

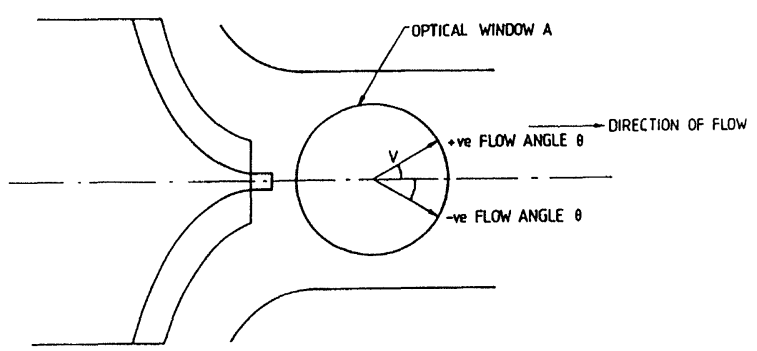

FIGURE 16 Definition of $+v e$ and - ve Flow angles. 


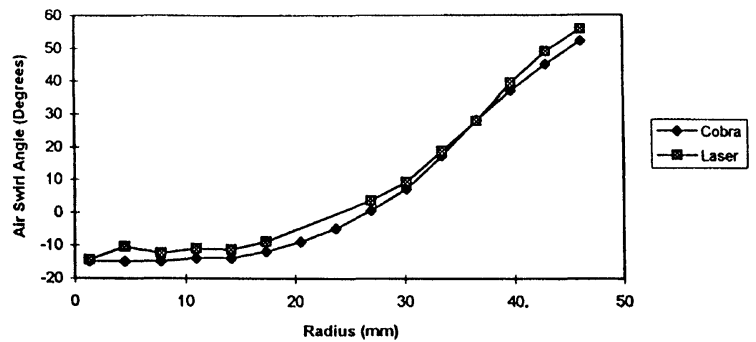

FIGURE 17 Comparison of laser and pressure probe measurements downstream the Turbine rotor.

Laser measurements were comparatively more difficult to be made at position B which lies only 35.5 $\mathrm{mm}$ away from the rotor, figure (5). Ten radial positions were selected for laser work. Figures (18 and 19) give the velocity and swirl angle variation across the duct for various flow conditions. Similar profiles for velocity and direction are in evidence as were obtained for window A. Velocity and flow angle profiles at this window, however, are incomplete due to measurement difficulties in the outer wall and core region. Figure (19) indicates a situation where the counter rotating core flow is more confined than in down stream plane (window A).

In order to examine the blade passing effect on the flow at window B, flow was strobed and laser measurements were carried out for different radial positions. Measurements were made relative to the fix rotor position and blade to blade passing period was divided into ten equal time profiles for various flow conditions. Figure (20) shows a typical result at one

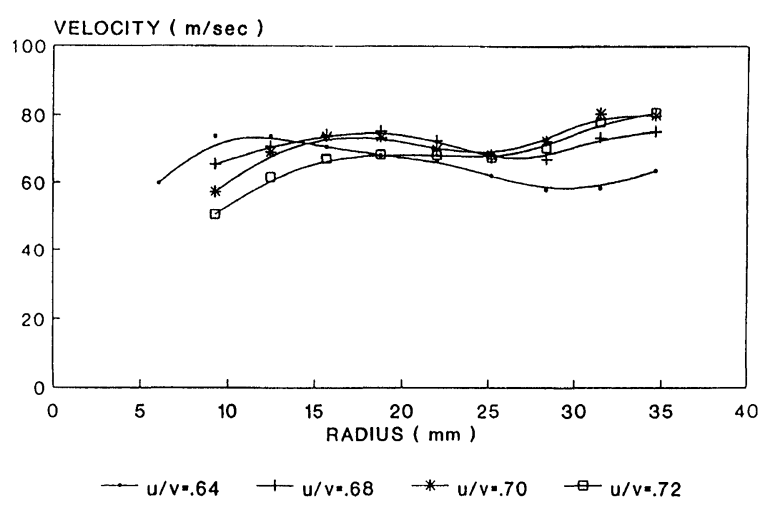

FIGURE 18 Laser Anemometry measurements downstream the Turbine rotor at station $\mathrm{B}$.

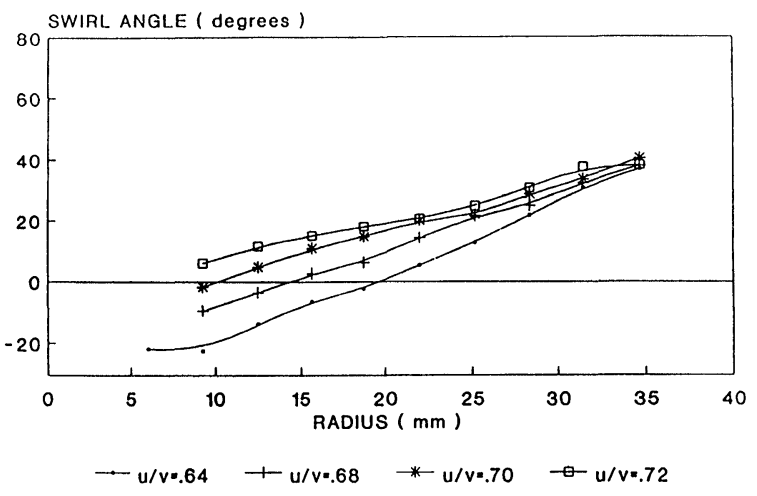

FIGURE 19 Laser Anemometry measurements downstream the Turbine rotor at station $\mathrm{B}$.

of the flow conditions. There is hardly any noticeable change in the blade to blade velocity and flow angle profiles, figure (20), and this is generally true for all the strobing measurements suggesting that any mixing has completed upstream at this station.

\section{CONCLUSION}

Experimental work has been carried out on a small radial inflow turbine which is a part of the small gas turbine power unit T-100 developed for aviation purposes. Laser anemometry measurements were taken at the inlet of the turbine rotor just downstream of the nozzle guide vanes. It was found very difficult to provide adequate optical access but after careful consid-

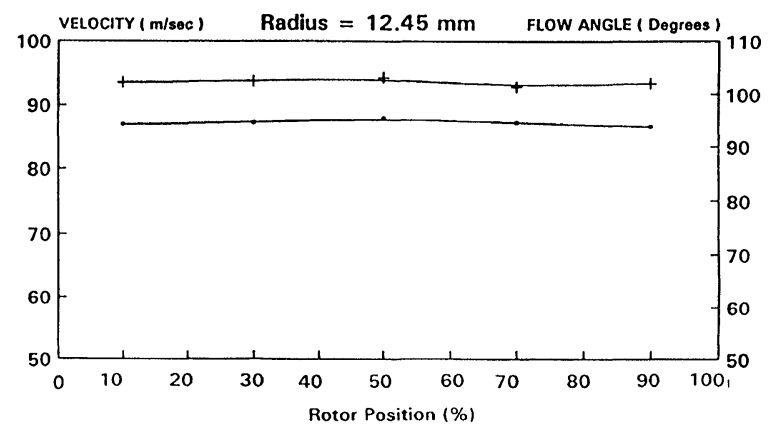

FIGURE 20 Strobing results downstream the Turbine rotor at section $\mathrm{B}$. 
erations five windows at different circumferential positions were provided. The laser work showed largely two dimensional flow in the area between the nozzle guide vanes and the rotor. Strobing results show hardly any unsteadiness in the flow caused by the passing blades at these positions. Down stream of the rotor, an ice layer on the glass prohibited any laser measurements but this problem was overcome and successful laser results were obtained. A cobra probe was used to compare the laser anemometry results. Both measuring techniques show the similar trends for velocity and flow angles at various running conditions. Measurements indicate a significant swirl in the direction of rotation towards the outerwall and a region of overturning (against the direction of rotation) in the core. The extent of this core increases in intensity and size with decreasing flow coefficients (U/V) and an increasing expansion ratio and was more confined closer to the turbine rotor trailing edge. No noticeable strobing effect could be observed down stream the rotor (window B) indicating that mixing was complete at this region.

\section{Acknowledgements}

The authors would like to acknowledge the support given to the project by the European Research Office (London) of the US Army. Also to thank Sunstrand Power Systems (San Diego) for the loan of equipment and to express their particular thanks to $\mathrm{C}$ Rodgers for his advice and encouragement.

\section{References}

Eroglu H., Tabakoff W., 1990. LDV Measurements of Turbulent Stresses in Radial Turbine Guide Vanes, ASME, 90-GT-75, Brussels, Belgium.

Gallus H.E., Lingner U., Ispas I., 1992. Experimental analysis of Transonic Flow through the vriable Nozzle of a Radial Inflow Turbine, ASME, 92-GT-90, Cologne, Germany.

Huntsman I., Hodson H.P., Hill S.H., 1991. The design and testing of a Radial Turbine for Aerodynamic Research, ASME, 91-GT220, Orlando, USA.

Jones A.C., 1994. Design and Test of a Small, High Pressure Ratio Radial Turbine, ASME, 94-GT-135, Hague, Netherlands.

Murugan D.M., Tabakoff W., Hamed A., 1994. Flow field investigation in the exit region of a Radial Inflow Turbine using LDV, ASME, 94-GT-101, Hague, Netherlands.

Napier J.C., 1991. Development of T-100 Multipurpose Small Power Unit, ASME, 91-GT-327, Orlando, USA.

Napier J.C., Thompson R.G., 1988. T-00 Multipurpose Power Unit: Technology for the Next Generation Auxiiliary Power Units, ASME, 88-GT-70

Pullen K.R., Baines, N.C., Hills S.H., 1992. The Design and Evaluation of a High Pressure Ratio Radial Turbine, ASME 92-GT93, Cologne, Germany.

Ross M.M., 1986. Transit Laser Anemometry Data Reduction for Flow in Industrial Turbomachinery, Optica Acta, V27, No 4, pp. $511-528$.

Schodl R., 1974. A laser dual beam method for flow measurements in Turbomachines, ASME 74-GT-157.

Zaidi S.H., Elder R.L., 1993. Nozzle Guide Vane Flow in Radial Inflow Turbines, AGARD Proc. Technology requirements for small gas turbines, Canada.

Zaidi S.H., Elder R.L., 1993. Investigation of Flow in a Radial Turbine using Laser Anemometry, ASME, 93-GT-55, Cincinnati, USA.

Zaidi S.H., Elder R.L. 1993. Study of hot flow through Turbines using Laser Anemometry, 5th Int. Conf. Laser Anemometry-Advances and Applications. Netherlands. 


\section{ait \\ ENERGY MATERIALS}

M A N E Y publishing

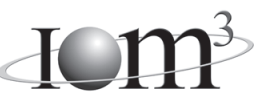

\section{Materials Science \& Engineering for Energy Systems}

Maney Publishing on behalf of the Institute of Materials, Minerals and Mining

The Institute of Materials, Minerals \& Mining

Economic and environmental factors are creating ever greater pressures for the efficient generation, transmission and use of energy. Materials developments are crucial to progress in all these areas: to innovation in design; to extending lifetime and maintenance intervals; and to successful operation in more demanding environments. Drawing together the broad community with interests in these areas, Energy Materials addresses materials needs in future energy generation, transmission, utilisation, conservation and storage. The journal covers thermal generation and gas turbines; renewable power (wind, wave, tidal, hydro, solar and geothermal); fuel cells (low and high temperature); materials issues relevant to biomass and biotechnology; nuclear power generation (fission and fusion); hydrogen generation and storage in the context of the 'hydrogen economy'; and the transmission and storage of the energy produced.

As well as publishing high-quality peer-reviewed research, Energy Materials promotes discussion of issues common to all sectors, through commissioned reviews and commentaries. The journal includes coverage of energy economics and policy, and broader social issues, since the political and legislative context influence research and investment decisions.

\section{CALL FOR PAPERS}

Contributions to the journal should be submitted online at http://ema.edmgr.com

To view the Notes for Contributors please visit: www.maney.co.uk/journals/notes/ema

Upon publication in 2006, this journal will be available via the Ingenta Connect journals service. To view free sample content online visit: www.ingentaconnect.com/content/maney

For further information please contact:

Maney Publishing UK

Tel: +44 (0)113 2497481 Fax: +44 (0)1132486983 Email: subscriptions@maney.co.uk

or

Maney Publishing North America

Tel (toll free): 8662975154 Fax: 6173546875 Email: maney@maneyusa.com

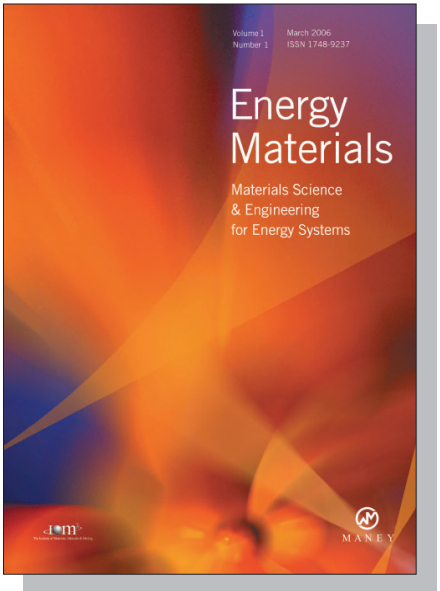

EDITORS

Dr Fujio Abe

NIMS, Japan

Dr John Hald, IPL-MPT, Technical University of Denmark, Denmark

Dr R Viswanathan, EPRI, USA

\section{SUBSCRIPTION INFORMATION}

Volume 1 (2006), 4 issues per year

Print ISSN: 1748-9237 Online ISSN: 1748-9245

Individual rate: $£ 76.00 / U S \$ 141.00$

Institutional rate: $£ 235.00 /$ US $\$ 435.00$

Online-only institutional rate: $£ 199.00 / U S \$ 367.00$

For special $\mathrm{IOM}^{3}$ member rates please email

subscriptions@maney.co.uk

\section{For further information or to subscribe online please visit www.maney.co.uk}



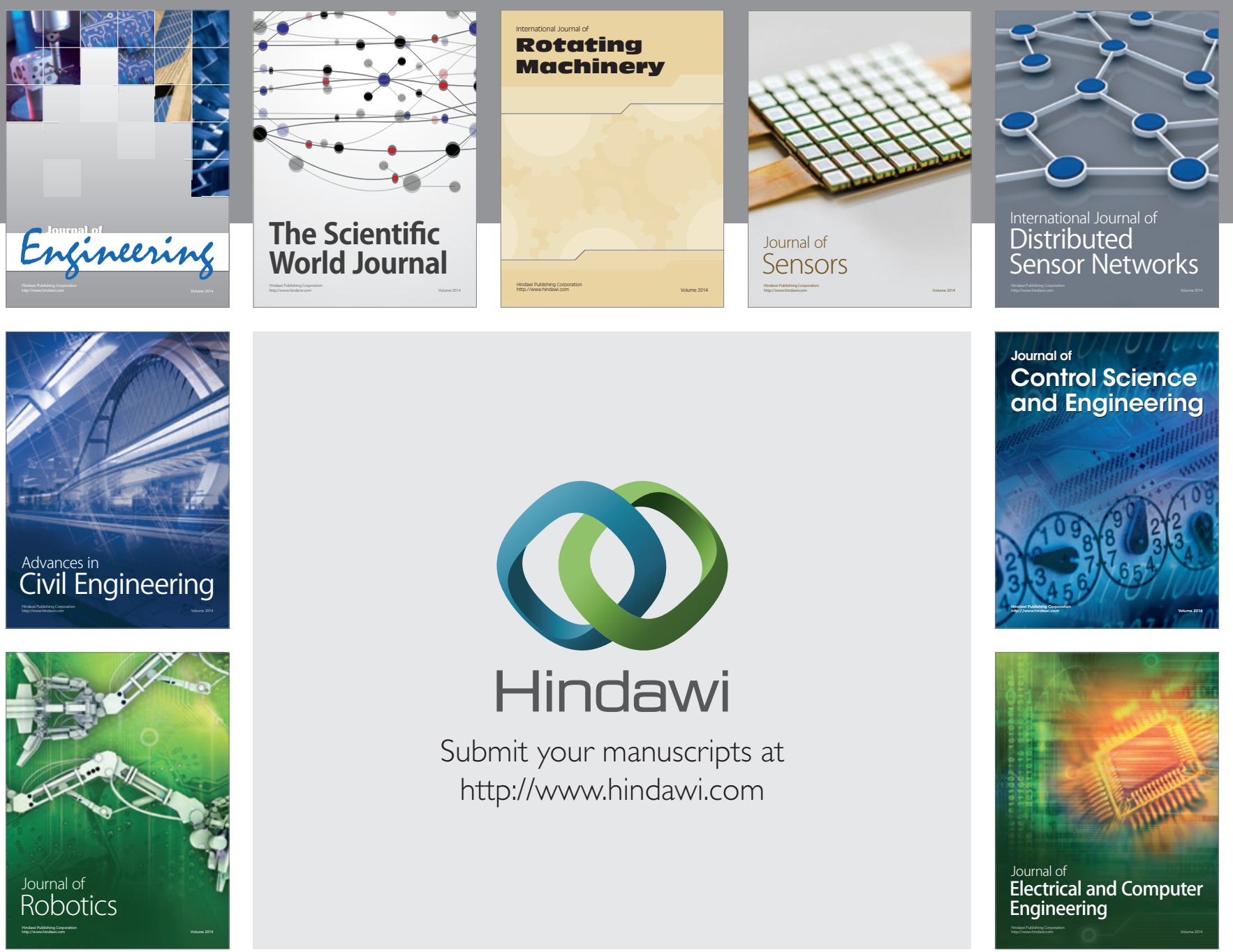

Submit your manuscripts at

http://www.hindawi.com
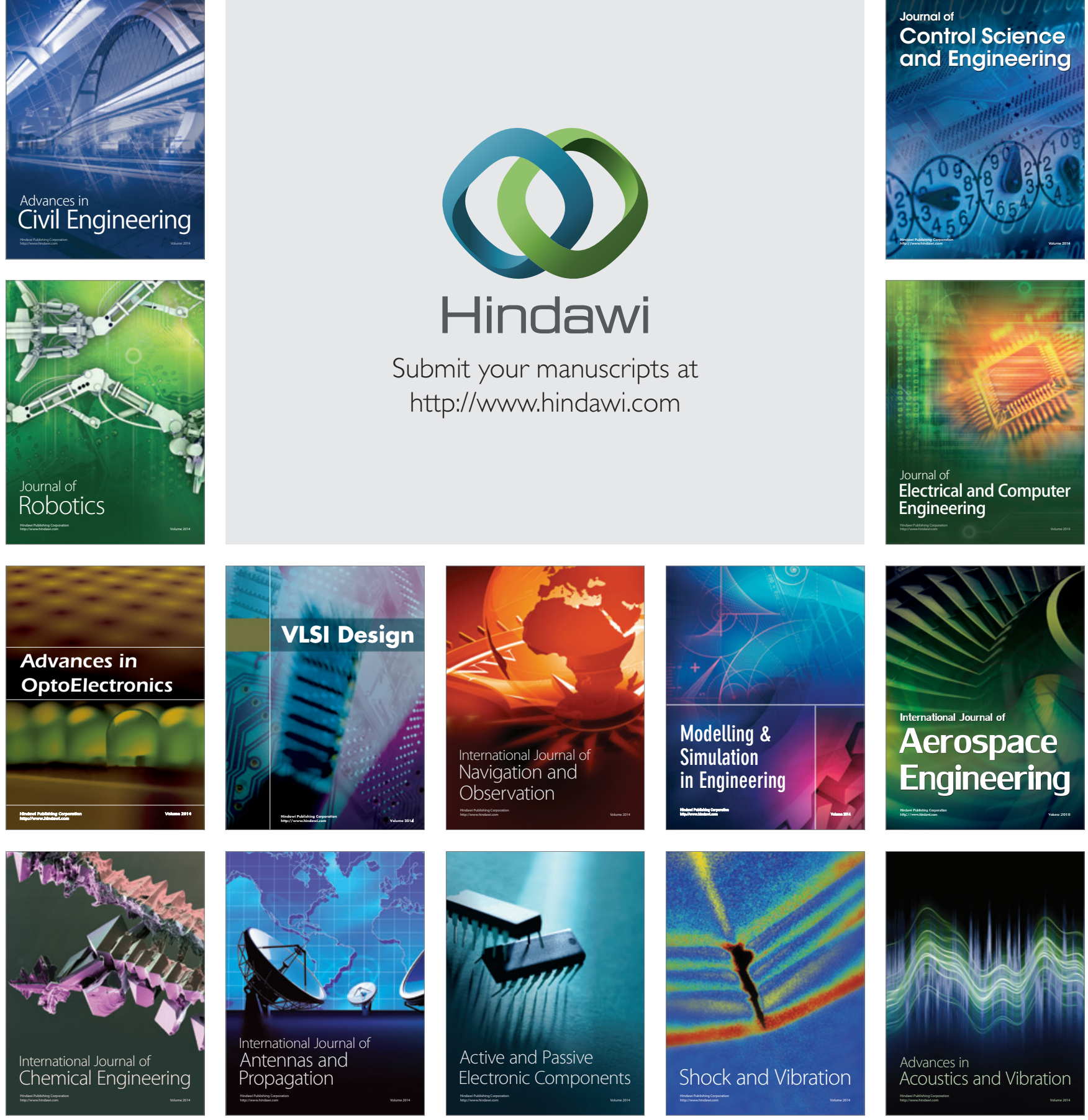